\title{
APPLICATION OF GEOGRAPHIC INFORMATION SYSTEM FOR THE POSTAL NETWORK ANALYSIS
}

\author{
Katarina Mostarac ${ }^{1,{ }^{*},}$ Zvonko Kavran ${ }^{1}$, Valentina Bešenić ${ }^{1}$
}

\begin{abstract}
The postal network is a comprehensive set of several subsets, namely, postal infrastructure (consisted of objects and means), transportation networks, and human resources. It is different in every country, following practices outlined by national and international regulation. Geographic Information System is a tool specialized for spatial data and network analysis. It can help identify shortcomings in a network environment, conditioned by a specific set of criteria and provisions. Spatial data and characteristics of the postal network are taken into consideration. The research area's transportation infrastructure and administrative data are also needed for quality analysis of the postal network. In this research, postal network organisation criteria are analysed on the example of Varaždin County. Conclusions on the status of the postal network as well as the suitability of the criteria and drawn.
\end{abstract}

Keywords postal network, GIS, spatial analysis, postal network organisation

\section{INTRODUCTION}

Geographic Information System (GIS) is a computer system primarily for spatial analysis. It allows users to gain useful intelligence from all data types. There are many definitions of GIS, depending on its primarily use. GIS is defined as a decision support system involving the integration of spatially referenced data in a problem-solving environment (Cowen, 1988), or a powerful set of tools for collecting, storing, retrieving, at will, transforming and displaying spatial data from the real world (Burrough, 1986). Furthermore, some authors define a GIS as a decision support system involving the integration of spatially referenced data in a problem-solving environment (Aronoff, 1989).

These many definitions of GIS show its complexity. Nowadays, GIS tools are complex and dynamic computer application areas due to their wide use in various technical and scientific disciplines. The data processed by the GIS is information related to the spatial aspects of objects, and more. This means that it allows to connect activities that are spatially correlated. GIS integrates data properties such as population statistics, natural resources with spatial data. GIS data are often accompanied by large databases, shown in attribute tables in the GIS applications. With the larger and detailed database, more spatial analysis is possible.

The issue of postal network optimization is widely investigated in the literature since it represents some of the major pillars of the postal organizations' strategy (Dobrodolac et al., 2016). For example, Ralević et al. (2016) implemented a nonparametric technique to measure the efficiency of the postal network. Furthermore, modern information and communication technologies are used to improve the postal

\footnotetext{
${ }^{1}$ University of Zagreb, Faculty of Transport Sciences, Vukelićeva 4, 10000 Zagreb, Republic of Croatia ${ }^{*}$ Corresponding author, phone: +385 1245 7712, e-mail: kmostarac@fpz.unizg.hr
} 
process (Dobrodolac et al., 2012) or to track the quality of postal network functioning (Švadlenka et al., 2016).

As mentioned, authors widely investigate postal network organisation, with emphasis on the optimisation of the processes. This is due to the fact that postal network provides a platform for fulfilment of the universal service obligation (USO). USO is the requirement of every country to provide its citizens postal services. This is the reason why the postal network is often subject of regulation. Furthermore, postal network presents basic infrastructure that facilitates international and foreign trade (ERGP, 2020).

Majority of European countries regulate the way postal network is organised (International Post Corporation, 2020). In the Republic of Croatia, the provision of postal services is regulated by the Postal Services Law (Republic of Croatia, 2012), and Ordinance on the provision of Universal Service (HAKOM, 2013). In most countries, the postal network is organised according to a set of criteria that universal service provider must meet to ensure universal service provision. However, it is evident that they vary, with no clear vision of how the criteria are chosen. Countries adapt the criteria according to their geographical demographic and other needs. It is therefore beneficial to analyse if these criteria are indeed appropriate for the postal network organisation.

However, one of the most popular technologies in the literature in recent years relates to the GIS application. Langford and Higgs (2010) used GIS to show variations in the postal network organisation due to network changes. Their research showed the importance of GIS analysis which can help policymakers in the provision of public (postal) service. Trubint (2012) used GIS for the network analysis, and optimal locations of the retail postal outlets. Higgs and Langford (2013) performed a GIS-based analysis of the postal service accessibility regarding rural and urban spatial contexts. Mostarac, Kavran and Feletar (2018) analysed accessibility of postal service applying GIS-based gravity model. Furthermore, Mostarac, Kavran and Rakić (2019) determined gravity model distance-decay parameters for the service accessibility scenarios. GIS was also used for the Two Step Floating Catchment Area (2SFCA) method application, where catchment areas were defined by the regulatory criteria (Mostarac, Kavran, Feletar, 2019.).

QGIS programming tool was used for spatial analysis of the postal network in this research. Within the QGIS programming interface, various functions allow users to create maps and compare, measure, and edit the created map data.

The aim of this research is to investigate advantages and emphasize disadvantages of the regulatory criteria for the postal network organisation. GIS based analysis has enabled in-depth analysis of the criteria, and possible guidelines for the implementation of other data into the model of postal network organisation.

\section{CHARATERISTSTICS OF POSTAL NETWORK AND VARAŽDIN COUNTY}

\subsection{Postal network}

A postal network must have elements that function and make it a network. The elements of a postal network are (HAKOM, 2013):

- Access points

- Post offices

- Self-service terminals

- Mailboxes

- Other elements that ensure the provision of postal services

The postal network of a public postal operator must be organized to include every settlement in the territory of a state, to provide universal postal service throughout the territory, under the same conditions 
for all users, of defined quality and affordable prices. In the Republic of Croatia, the universal service provider is Hrvatska pošta d.d. (HP) (Croatian Post). Croatian Regulatory Authority for Network Industries (HAKOM) is the regulator in the field of postal services.

HP has a crucial role in achieving the optimality of the postal network. This means that the elements of the postal network must be organized in a way accessible to all citizens. The accessibility of postal network elements is ensured by regulatory criteria, determined by international and domestic regulations, which the universal service provider must meet.

In the Republic of Croatia, the following criteria for the density of the network of access points are in legal force HAKOM, 2013):

- Criterion I: One post office operates on average on an area of no more than $80 \mathrm{~km} 2$

- Criterion II: One post office operates on average for a maximum of 6,000 inhabitants

- Criterion III: The universal service provider is obliged to establish a network of access points in populated areas so that the distance between access points is a maximum of 5,000 m.

\subsection{Spatial characteristics of Varaždin County}

Varaždin County is located in the northwestern part of the Republic of Croatia and covers $1.261 .29 \mathrm{~km}^{2}$. Table 1 shows the essential characteristics of Varaždin County: the number of settlements (302), municipalities (22) and cities (6), the number of inhabitants and population density.

Tab. 1. Essential characteristics of Varaždin County (source: Croatian Bureau of Statistics, 2011)

\begin{tabular}{ll}
\hline Varaždin County & \\
\hline County area $\left[\mathrm{km}^{2}\right]$ & 1261,29 \\
Number of inhabitants (2011) & 175951 \\
Population density [inhabitant $\left./ \mathrm{km}^{2}\right]$ & 139,42 \\
Number of cities & 6 \\
Number of municipalities & 22 \\
Number of settlements & 302 \\
\hline
\end{tabular}

In the area of Varaždin County, there are total of 32 post offices. The locations of post offices are shown in Figure 1. Each city or municipality has at least one post office located in it. 




Fig. 1. The postal network of Varaždin County (source: authors)

All post offices in Varaždin County are connected through the Postal Centre (PC) for processing postal items. The PC is located within the postal centre of Varaždin with the task of collecting and distributing postal items, as well as transporting them to the main postal centre in Zagreb.

\section{SPATIAL ANALYSIS OF THE POSTAL NETWORK}

The postal network is most often analysed to find the optimal solution for fulfilling the obligation to provide universal postal service. In this paper, the postal network's geographical analysis is carried out using the beforementioned criteria (I, II, and III). Therefore, according to the previously mentioned criteria of access point density, the postal network of Varaždin County was analysed.

\subsection{Criterion I}

Consequently, a map was made using GIS software, showing Criterion I, where one post office must cover an area of $80 \mathrm{~km}^{2}$ (or radius of $5 \mathrm{~km}$ of air distance). Criterion I, Varaždin County status is shown in Figure 2 , where the post office service areas are shown. 


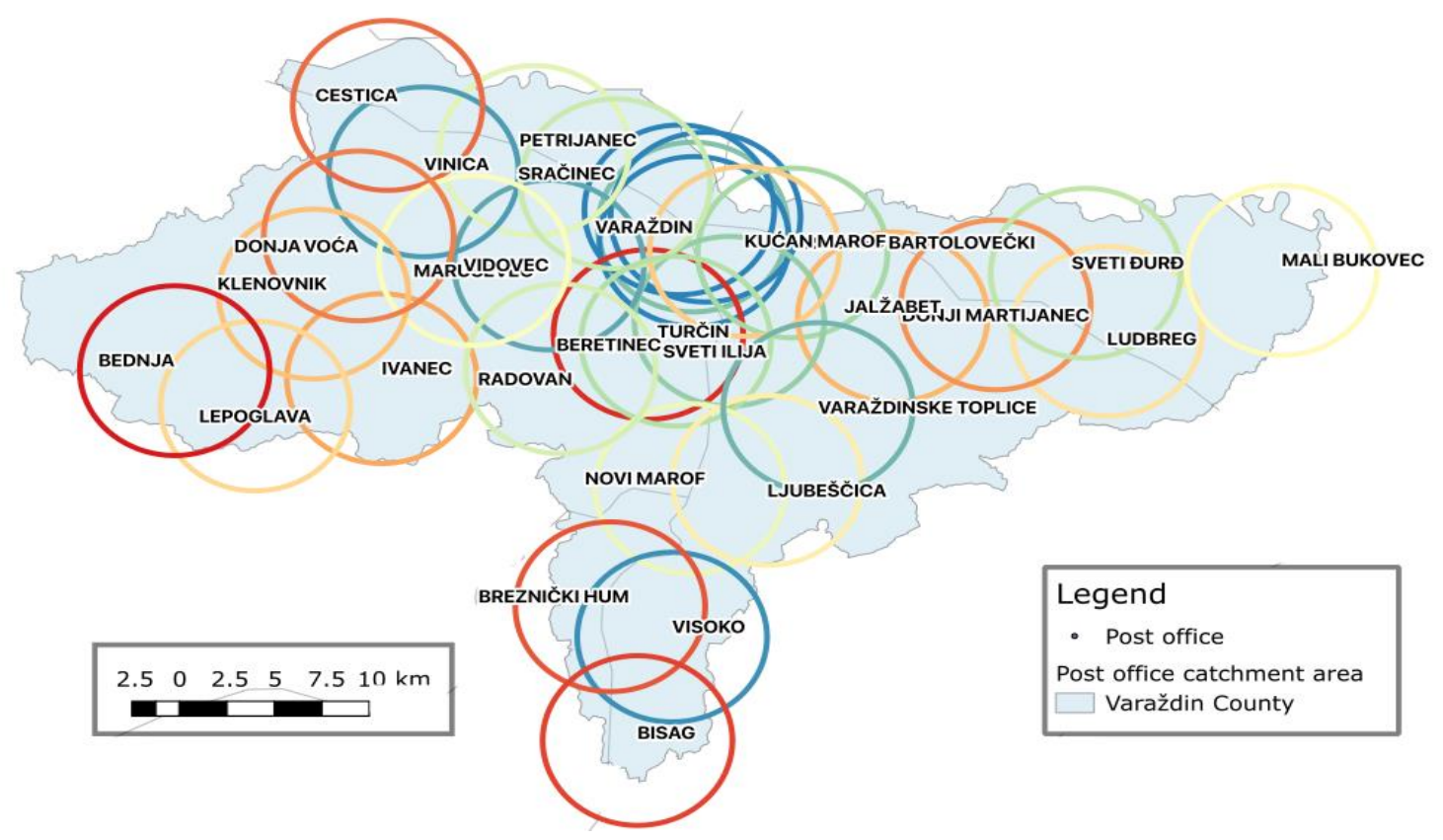

Fig. 2. Post office coverage in the Varaždin County, (source: authors)

The post office network is quite dense, leaving some areas inaccessible to postal service, mainly far west and east parts of the County.

To better analyse and determine the accessibility of the postal network of Varaždin County other data should also be considered. We further analyse land use data. The type of land can significantly contribute to the distribution of post office locations. Figure 3 shows the land use of the western and central parts of Varaždin County. Figure 3 is an orthophoto image of the Varaždin County, accessible at the State Geodetic Administrations' official web page, providing geographic services (Geoportal, 2020). It is evident the far west part with no post office coverage is an area covered in woods.

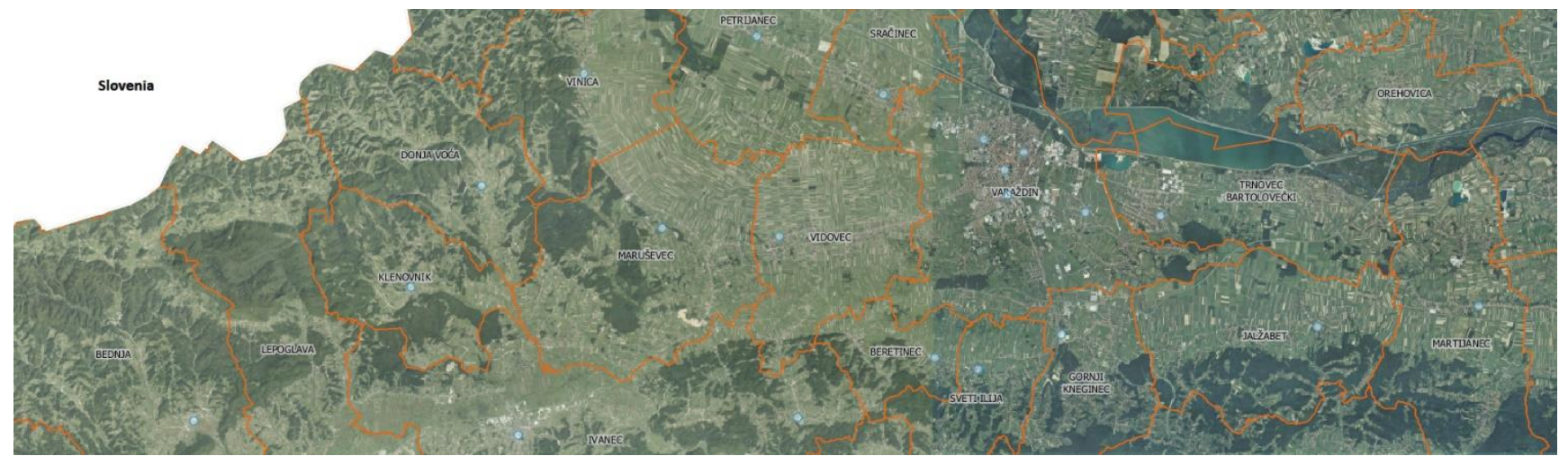

Fig. 3. Land use in Varaždin county (Source: Geoportal, 2020)

If Figures 2 and 3 are compared, it is evident that the areas inaccessible to the postal service are mainly wood areas. The East part of the County is primarily an agricultural area. However, when analysing the County's entire territory, it can be concluded that the network of post offices optimally covers Varaždin County.

\subsection{Criterion II}

Data on the population and households should be considered to analyse the number of people a postal office serves. Table 2 shows the list of post offices in Varaždin County including the number of inhabitants and households. It is evident that in the city of Varaždin four post offices are located, one of which is a PC. Other cities and municipalities in their area have at least one post office. 
Tab. 2. Post offices main demographic characteristics (source: authors, Croatian Bureau of Statistics, 2011)

\begin{tabular}{|c|c|c|c|}
\hline Postal code & Name of PO & No of inhabitants & No of households \\
\hline \multicolumn{4}{|l|}{42000} \\
\hline 42103 & \multirow{3}{*}{ VARAŽDIN } & \multirow{3}{*}{38746} & \multirow{3}{*}{14624} \\
\hline 42104 & & & \\
\hline 42105 & & & \\
\hline 42201 & BERETINEC & 1040 & 314 \\
\hline 42202 & TRNOVEC BARTOLOVEČKI & 4190 & 1289 \\
\hline 42203 & JALŽABET & 1066 & 240 \\
\hline 42204 & TURČIN & 918 & 304 \\
\hline 42205 & VIDOVEC & 858 & 239 \\
\hline 42206 & PETRIJANEC & 1431 & 409 \\
\hline 42207 & VINICA & 1077 & 326 \\
\hline 42208 & CESTICA & 503 & 140 \\
\hline 42209 & SRAČINEC & 3891 & 1173 \\
\hline 42212 & KUĆAN MAROF & 1388 & 427 \\
\hline 42214 & SVETI ILIJA & 616 & 171 \\
\hline 42220 & NOVI MAROF & 1936 & 669 \\
\hline 42222 & LJUBEŠČICA & 1264 & 429 \\
\hline 42223 & VARAŽDINSKE TOPLICE & 1763 & 629 \\
\hline 42224 & VISOKO & 488 & 154 \\
\hline 42225 & BREZNIČKI HUM & 488 & 166 \\
\hline 42226 & BISAG & 155 & 50 \\
\hline 42230 & LUDBREG & 3594 & 1245 \\
\hline 42231 & MALI BUKOVEC & 728 & 224 \\
\hline 42232 & MARTIJANEC & 419 & 126 \\
\hline 42233 & SVETI ĐURĐ & 646 & 185 \\
\hline 42240 & IVANEC & 5234 & 4097 \\
\hline 42242 & RADOVAN & 375 & 104 \\
\hline 42243 & MARUŠEVEC & 460 & 148 \\
\hline 42244 & KLENOVNIK & 977 & 297 \\
\hline 42245 & DONJA VOĆA & 1074 & 335 \\
\hline 42250 & LEPOGLAVA & 4164 & 1085 \\
\hline 42253 & BEDNJA & 679 & 299 \\
\hline
\end{tabular}

Criterion II stipulates that one post office operates for a maximum of 6,000 inhabitants. Post offices in the city of Varaždin serve more than the 6,000 inhabitants. According to the table data, there are four post offices in Varaždin with 38,746 inhabitants. Therefore, one post office in the city of Varaždin operates for almost 9,700 inhabitants.

A comparison of the data from Table 2 and Figure 2, shows that the post offices' location is satisfactory. However, this criterion shows another problem. According to the data presented in Table 2, many post offices serve a relatively small number of service users (inhabitants).

The question arises of the cost-effectiveness of those offices that serve a small number of inhabitants. For example, post office 42226 serves only 155 inhabitants, 42242 serves 375, and quite a few offices are serving four or five hundred inhabitants. 


\subsection{Criterion III}

For analysis of the Criterion III, distances between a post office and surrounding offices are measured. According to this criterion, the universal service provider must establish a network of access points in populated areas so that the distance between access points is a maximum of 5,000 [m]. Data measured and obtained by the QGIS tool are shown in Table 3.

Tab. 3. Distance between post offices (source: authors)

\begin{tabular}{|c|c|c|}
\hline \multicolumn{2}{|c|}{ PO where the distance is measured } & \multirow{2}{*}{$\begin{array}{l}\text { Air distance [km] } \\
5,21\end{array}$} \\
\hline \multirow{3}{*}{ LEPOGLAVA } & BEDNJA & \\
\hline & KLENOVNIK & 7,27 \\
\hline & IVANEC & 6,43 \\
\hline \multirow{4}{*}{ IVANEC } & KLENOVNIK & 6,14 \\
\hline & DONJA VOĆA & 8,50 \\
\hline & MARUŠEVEC & 8,15 \\
\hline & RADOVAN & 9,39 \\
\hline \multirow{4}{*}{ DONJA VOĆA } & CESTICA & 7,89 \\
\hline & VINICA & 5,07 \\
\hline & MARUŠEVEC & 6,07 \\
\hline & KLENOVNIK & 4,22 \\
\hline \multirow{3}{*}{ VINICA } & CESTICA & 4,38 \\
\hline & PETRIJANEC & 5,83 \\
\hline & MARUŠEVEC & 5,95 \\
\hline \multirow{4}{*}{ PETRIJANEC } & CESTICA & 7,98 \\
\hline & MARUŠEVEC & 7,51 \\
\hline & VIDOVEC & 7,22 \\
\hline & SRAČINEC & 4,91 \\
\hline \multirow{3}{*}{ MARUŠEVEC } & SRAČINEC & 9,00 \\
\hline & VIDOVEC & 5,68 \\
\hline & RADOVAN & 7,75 \\
\hline \multirow{4}{*}{ VIDOVEC } & SRAČINEC & 5,11 \\
\hline & BERETINEC & 5,56 \\
\hline & RADOVAN & 6,16 \\
\hline & SVETI ILIJA & 6,82 \\
\hline \multirow{2}{*}{ RADOVAN } & BERETINEC & 5,01 \\
\hline & SVETI ILIJA & 6,24 \\
\hline \multirow{8}{*}{ SVETI ILIJA } & BERETINEC & 1,46 \\
\hline & TURČIN & 2,88 \\
\hline & NOVI MAROF & 8,79 \\
\hline & VARAŽDIN 42000 & 6,73 \\
\hline & VARAŽDIN 42103 & 7,42 \\
\hline & VARAŽDIN 42104 & 5,94 \\
\hline & VARAŽDIN 42105 & 7,72 \\
\hline & KUĆAN MAROF & 6,47 \\
\hline \multirow{5}{*}{ SRAČINEC } & BERETINEC & 9,00 \\
\hline & VARAŽDIN 42000 & 4,73 \\
\hline & VARAŽDIN 42103 & 5,03 \\
\hline & VARAŽDIN 42104 & 5,35 \\
\hline & VARAŽDIN 42105 & 3,66 \\
\hline \multirow{2}{*}{ VARAŽDIN 42000} & VARAŽDIN 42103 & 0,866 \\
\hline & VARAŽDIN 42104 & 0,887 \\
\hline
\end{tabular}




\begin{tabular}{lll}
\hline & VARAŽDIN 42 105 & 1,20 \\
& BERETINEC & 6,75 \\
& TURČIN & 6,25 \\
& KUĆAN MAROF & 3,03 \\
& TRNOVEC & 5,46 \\
\hline & KUĆAN MAROF & 4,62 \\
& TRNOVEC & 5,47 \\
& BERETINEC & 4,21 \\
\multirow{2}{*}{ TURČIN } & NOVI MAROF & 9,78 \\
& LJUBEŠĆICA & 9,24 \\
& VARAŽDINSKE TOPLICE & 6,71 \\
\hline \multirow{2}{*}{ TRNOVEC } & KUĆAN MAROF & 2,51 \\
& VARAŽDINSKE TOPLICE & 9,15 \\
\hline \multirow{2}{*}{ DONJI MARTIJANEC } & JALŽABET & 6,47 \\
\hline \multirow{2}{*}{ LUDBREG } & JALŽABET & 5,47 \\
& SVETI ĐURĐ & 5,11 \\
& LUDBREG & 6,00 \\
\hline \multirow{2}{*}{ VARAŽDINSKE TOPLICE } & SVETI ĐURĐ & 3,67 \\
& MALI BUKOVEC & 9,88 \\
\hline \multirow{2}{*}{ VISOKO } & JALŽABET & 6,56 \\
& LJUBEŠĆICA & 5,00 \\
& NOVI MAROF & 8,25 \\
& KUĆAN MAROF & 10,06 \\
\hline
\end{tabular}

According to the obtained data, many post offices are at a greater distance than $5 \mathrm{~km}$. However, some post offices are at a relatively smaller distance. For instance, the distance between post offices in Sveti Ilija and Beretinec; Sveti Ilija and Turčin; Trnovec and Kućan Marof is under three kilometres. It should be noted that Criterion III refers to all access points, not only post offices. Therefore, mailboxes, self-service terminals, and other ways of post service provision could also be included in the analysis. In this study, we have limited our research to post offices.

\subsection{Further spatial analysis of the postal network}

Spatial analysis of the criteria shows a way to easily and straightforward perception of the postal network organisation. However, further analysis should be conducted to analyse the network that criteria fail to observe. Some of the problems can be identified here:

- Criteria are mutually exclusive, counting only for the area or number of the inhabitants that post the office is serving.

- Real distance is not counted for, but air distance which is not a good indicator when specific landmarks are concerned, such as islands, mountain, or large urban areas.

- Focus is put on a post office location, not accounting for the layout of the household locations, which is crucial in mostly rural areas.

Figure 4 shows all the inhabited places in Varaždin County. This data layer is obtained by the Open Street Map (OSM, 2020) data and includes cities, towns, villages, hamlets, and other settlements. The map shows locations of post offices regarding all the settlements that should be covered by the postal service. 
This type of data could be useful for providing alternative solutions for the postal network organisation. For example, for settlements at a further distance from the post office, provision of the postal services could be arranged via mobile post offices, postman, after-hours shifts, etc.

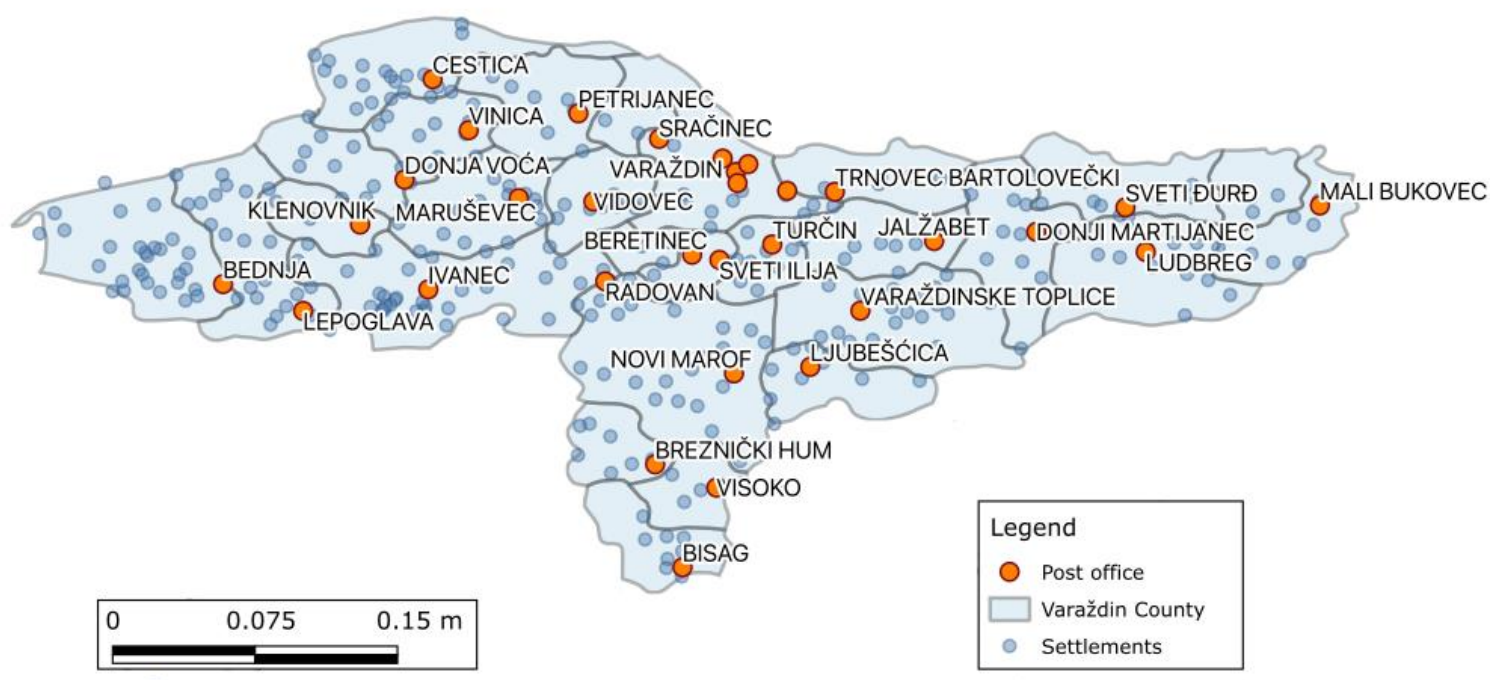

Fig. 4. Inhabited places (settlements) in Varaždin County (source: authors)

When analysing settlements around the post office in Bednja, it is evident that they are quite dispersed. But settlements around post offices in Sveti Ilija, Beretince, Turčin (offices under 3 kilometres distance according to criterion III) are not dispersed and are quite well covered by the existing post offices.

Additionally, the road transport data layer can be used for postal network analysis. Figure 5 shows the road transport network and the public transportation network stations (including railway and bus stations). These data layers (OSM, 2020) help determine accessibility to postal services. For example, some post offices have several public transportation stations in their vicinity, while others have none.

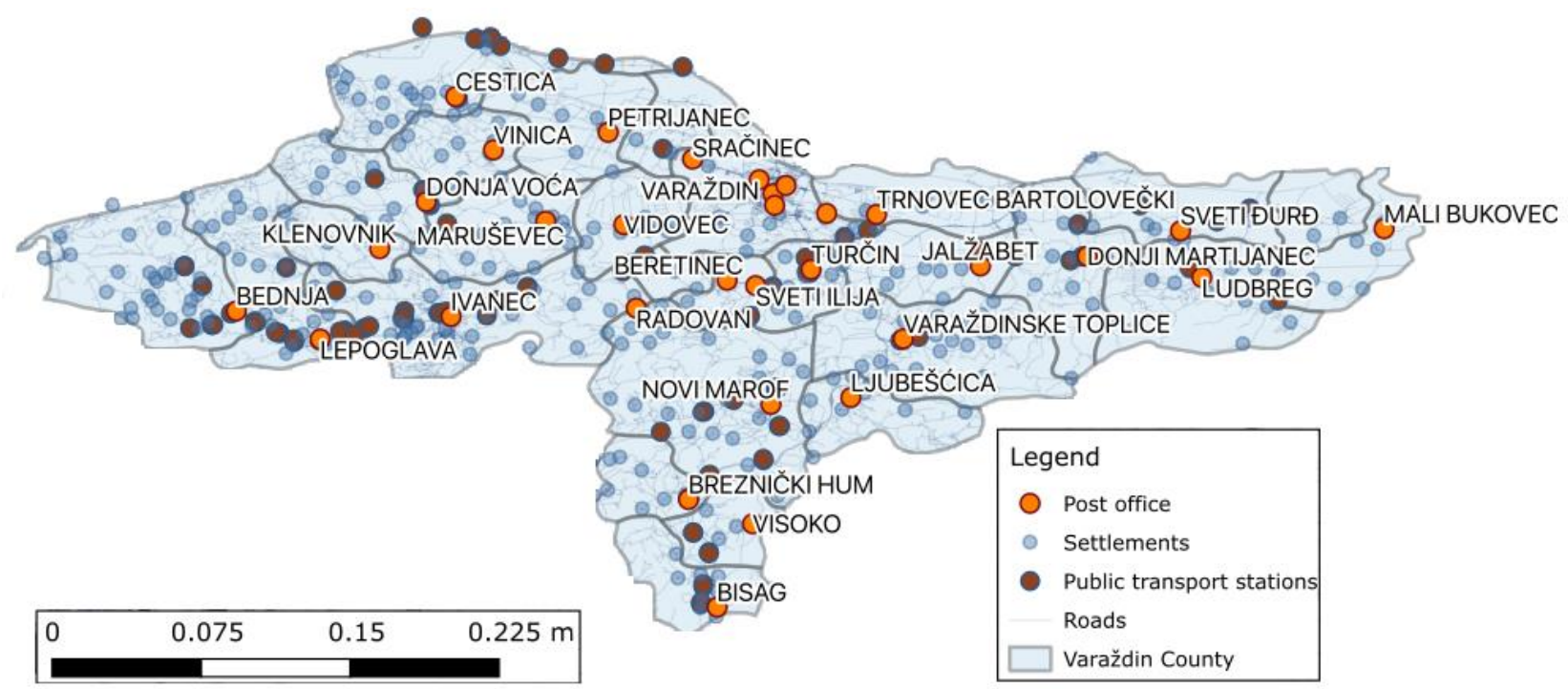

Fig. 5. The Public transportation network of Varaždin County (source: authors)

This type of data should help determine alternative ways of providing postal services to the remote population. It is also a reasonable basis for planning transportation costs, routes, delivery areas, and so on. 


\section{DISCUSSION}

It is important to notice that the study is based on the criteria that the postal services market regulator has put into effect in the Republic of Croatia. These criteria are limited to the service area and population served by one post office and the distance between access points. Goal of the research was to determine if the criteria are well defined in the context of the Republic of Croatia. On the example of the Varaždin County it is evident that the status of the postal network is satisfactory. County is well covered by the postal network, with no major inhabited areas where the service is inaccessible. Reason for this lies in the geographical characteristics of the Varaždin County, where the compact shape of the County and locations of the settlements are evidently compatible to this kind of criteria. We can conclude that the areas with similar characteristics as Varaždin County can organise postal network with satisfactory results, using these criteria.

However, question is if these criteria will be suitable for postal network organisation when different landmarks are concerned. For more comprehensive analysis, other countries' criteria, land use and geographical characteristics should also be considered. For example, determining percentage of population located at defined distances from the postal network access points. Analysis of the real terrain network distances can also be beneficial. All these various criteria are presumed to differently affect various landmarks such as mountain areas, island or seaside areas, remote rural or urban areas.

Other criteria should also be considered to get an in-depth analysis of the status of the postal network. First, the demographic characteristics of the population should be included in the study. Age, working population, daily migrations, etc. are just some of the data that could generally affect the postal network's future organization.

Furthermore, post offices' status, such as the number of services they provide, income, profit, and other important data, can also affect how access points are organised. However, when analysing the post offices performance, it is important to combine these data with the population's data. A model that incorporates population's habits, daily migrations, and legislative criteria can result in a more personalised approach to postal network organisation.

For instance, mobile post offices can be introduced into remote areas and areas where the older population lives. The frequency of providing postal services through the mobile office can depend on when this population mostly uses postal services. On the other hand, pick up and drop off terminals (PUDO) can be introduced as access points targeting mostly younger and working populations. Locations of these terminals will depend on the workplaces' location, daily migration routes (near highways, gas stations, public transportation stations, etc.).

\section{CONCLUSIONS}

Varaždin County has a population of 175,951 inhabitants and around three hundred settlements. It is necessary for the universal service provider to strategically distribute post offices to achieve maximum coverage of the entire area of the County. Analysis of County and postal network's spatial characteristics were made using spatial analysis tools and geospatial data sets.

According to the analysis using the criteria for the density of the access points (Criteria I, II and III) it can be determined that the postal network of Varaždin County is organised in satisfactory conditions. Also, the analysis and comparison of data obtained using the QGIS program showed that post offices are in strategic locations to maintain optimal coverage of the entire area of Varaždin County. In some parts of the County, there are places with a high density of post offices and are working for a relatively small number of inhabitants. The universal service provider could introduce alternative technologies instead of post offices that would cover the necessary user needs. One option is mobile post offices or PUDO devices. Changes in the organisation of the postal network can be monitored and planned using GIS-based data layers. 


\section{References}

Aronoff, S. 1989. Geographic Information Systems: A Management Perspective. Ottawa, Canada: WDC Publications.

Burrough, P. A., 1986. Principles of Geographical Information Systems for Land Resources Assessment. Oxford University Press, N.Y.

Cowen, D. J., 1988, GIS versus CAD versus DBMS: what are the differences? Photogrammetric Engineering and Remote Sensing 54, 1551-4.

Croatian Bureau of Statistics, 2011. Census of Population, Households and Dwellings 2011. Available at: https://www.dzs.hr/Hrv/censuses/census2011/firstres/censusfirstres.htm

Dobrodolac, M., Lazarević, D., Švadlenka, L. and Živanović, M. 2016. A study on the competitive strategy of the universal postal service provider. Technology Analysis \& Strategic Management, 28(8), pp. 935-949. doi: https://doi.org/10.1080/09537325.2016.1180357

Dobrodolac, M., Marković, G., Čubranić-Dobrodolac, M. and Čičević, S. 2012. A model for the allocation of limited resources for technological improvement: A case of courier service. Engineering Economics, 23(4), pp. 348-356. doi: https://doi.org/10.5755/i01.ee.23.4.1502

ERGP. 2020. European Regulators Group for Postal Services (ERGP PL II (20) 28). ERGP Report on Interconnection Models and Access to International Postal Networks. Available at: https://ec.europa.eu/docsroom/documents/44094

HAKOM. 2013. Croatian Regulatory Authority for Network Industries. Official Gazette, 2013, 41/13. [In Croatian: Pravilnik o obavljanju univerzalne usluge].

Geoportal. 2020. National Spatial Data Infrastructure. [Online]. Available at: https:/geoportal.dgu.hr/ [Accessed: 20. 01. 2021.]

Higgs, G., Langford, M. 2013. Investigating the Validity of Rural-Urban Distinctions in the Impacts of Changing Service Provision: The Example of Postal Service Reconfiguration in Wales, Geoforum, 47, pp. 53 -64 .

International Post Corporation. 2020. IPC Postal Regulatory Database. Available at: https://www.ipc.be/services/markets-and-regulations/regulations/ipc-regulatory-database

Langford, M., Higgs, G. 2010. Accessibility and Public Service Provision: Evaluating the Impacts of the Post Office Network Change Programme in the UK, Transactions of the Institute of British Geographers, New Series, 35(4), pp. 585 - 601.

Mostarac, K., Kavran, Z., i Feletar, P. 2018. Determining Accessibility of Post Network Elements with Application of Gravity Method, Podravina, 17(33), pp. 63-73. Available at: https://hrcak.srce.hr/204294

Mostarac, K., Kavran, Z., i Rakić, E. 2019. Accessibility of Universal Postal Service According to Access Points Density Criteria: Case Study of Bjelovar-Bilogora County, Croatia, Promet - Traffic\&Transportation, 31(2), pp. 173-183. DOI: https://doi.org/10.7307/ptt.v31i2.3019

Mostarac, K., Kavran, Z., i Feletar, P. 2019. Application of catchment area method for determining post office accessibility: case study Bjelovar-Bilogora County, Geoadria, 24(1), pp. 53-70. doi: https://doi.org/10.15291/geoadria.2858

Ralević, P., Dobrodolac, M. and Marković, D. 2016. Using a nonparametric technique to measure the cost efficiency of postal delivery branches. Central European Journal of Operations Research, 24(3), pp. 637-657. DOI: https://doi.org/10.1007/s10100-014-0369-0

Republic of Croatia. 2012. NN 144/12, 153/13, 78/15, 110/19. [In Croatia: Zakon o poštanskim uslugama]. Available at: https://www.zakon.hr/z/249/Zakon-0-po\%C5\%A1tanskim-uslugama 
Trubint, N. 2012. A GIS Application to Explore Postal Retail Outlet Locations, Promet Traffic\&Transportation, 24(2), pp. 161-168. doi: https://doi.org/10.7307/ptt.v24i2.288

Švadlenka, L., Dobrodolac, M. and Blagojević, M. 2016. Application of tracking technologies in the postal system. In the Proceedings of International Conference on Traffic and Transport Engineering - ICTTE Belgrade 2016, Belgrade, November 24-25. Belgrade, Serbia: City Net Scientific Research Center Ltd, pp. 980-990. 